\title{
Effect of Heavy Metals (Cu and Zn) on the Content of Photosynthetic Pigments in the Cells of Algae Chlorella vulgaris
}

\author{
Paweł Kondzior ${ }^{1 *}$, Andrzej Butarewicz ${ }^{1}$ \\ 1 Department of Chemistry, Biology and Biotechnology, Faculty of Civil and Environmental Engineering, \\ Bialystok University of Technology, ul. Wiejska 45 E, 15-351 Bialystok, Poland \\ * Corresponding author's e-mail: p.kondzior@doktoranci.pb.edu.pl
}

\begin{abstract}
The purpose of this paper is to determine the effect of heavy metals on the photosynthetic pigments of chlorophyll $\mathrm{a}, \mathrm{b}$ and the carotenoids found in the cells of algae Chlorella vulgaris. In order to analyze the influence of heavy metals on Chlorella vulgaris algae, two heavy metals were chosen, i.e. copper and zinc. The samples for analysis were collected daily for 7 days. Copper(II) sulphate, which is widely regarded as an algicide, was used in the study. Chlorella vulgaris grows at the highest concentration tested, amounting to $0.15 \mathrm{mg} \mathrm{CuSO}_{4} / \mathrm{dm}^{3}$. In the trial with a concentration of $0.15 \mathrm{mg} \mathrm{CuSO} / \mathrm{dm}^{3}$, a decrease in the content of chlorophyll was observed, which was lower by $63 \%$ in comparison to the control sample, 7 days after incubation was observed. In the second study using zinc(II) sulphate at a concentration of $100 \mathrm{mg} \mathrm{ZnSO} / \mathrm{dm}^{3}$, the death of Chlorella vulgaris was observed after 5 days of incubation. In subsequent tests with lower concentrations of zinc(II) sulphate, Chlorella vulgaris is growing, but with lesser dynamics than in the case of the control sample. The increase in the content of photosynthetic pigments, along with the incubation time, indicates the development of algae breeding. The conducted research shows that the Chlorella vulgaris algae has a specific resistance to the presence of the elevated content of tested heavy metals in the breeding medium.
\end{abstract}

Keywords: heavy metals, photosynthetic pigments, copper, zinc, algae, Chlorella vulgaris

\section{INTRODUCTION}

The anthropogenic impact causes an increasing pollution of the natural environment. The main sources of pollution involve the metallurgical, energy, mining and transport industries. Heavy metals such as zinc, cadmium, lead, copper, chrome and arsenic infiltrate to the environment. This directly affects the proper development and stability of individual ecosystems. Heavy metals are accumulated in the plant and animal organisms. They are characterized by a long half-life and are accumulated in the ground and then washed into surface waters. The rate of this process depends on the physical and chemical properties of the soil and the compounds in which these elements occur. The effect of heavy metals on algae is not sufficiently known due to their complex influence [Węglarzy 2007].
Algae are a wide group of mainly autotrophic organisms. They may occur in the form of single-cell or multicellular organisms. Under optimal conditions, they are characterized by a rapid growth. In the natural environment, it is often an intense growth of algae, called algal bloom. This is a phenomenon that threatens the ecosystem, especially when the main species of developing algae produce harmful toxins. Improper fertilization of cultivated fields and insufficient wastewater treatment increases the amount of biogenic compounds in surface waters [Kondzior 2017]. Algicides are used against excessively growing algae in surface waters; most often they constitute copper-containing chemicals. U. S. The Environmental Protection Agency has placed copper on the list of priority pollutants. In addition, EU countries are working on Environmental Quality Standards (EQS) for copper in surface water 
under the EU water framework directive. Unfortunately, agriculture still uses the biocides based on copper compounds in the fight against fungal diseases, for example in the cultivation of grapes and citrus fruits. This may cause a local increase of this element in the surface waters [Hochmuth et al. 2014]. Copper is an essential micronutrient for many living organisms, but it's demand is small. However, lack thereof results in a reduction in the functioning of enzyme systems, subsequently causing a disturbance of metabolism in the body. In the case of plants, it occurs in a large number of chloroplasts. Copper also constitutes a component of plastocyanin, or chloroplast protein responsible for the electron transport during the photosynthesis [Bandurska 2007]. It participates in the metabolism of nitrogen and sugar compounds in oxidation-reduction reactions, responsible for the proper course of photosynthesis and respiration. Excessive copper contents are toxic [Gabryś et al. 2005].

In the research, a second heavy metal was used, i.e. zinc. In plants, it affects the activity of many enzymes. Zinc is involved in the regulation of sugar metabolism and protein synthesis. It occurs in the cell membranes and in the ribosome structure. Together with copper, it creates superoxide dismutase (SOD) [Gabryś et al. 2005]. In industry, zinc can be used in the galvanizing process to protect steel and iron against corrosion. This process causes the formation of sewage from rinsing water and acid pickling baths, which are contaminated with heavy metals such as: zinc, iron, copper and hexavalent chromium which is very harmful to the environment. Chemical precipitation, membrane filtration, electrochemical processes, ion exchange and absorption or biosorption are used for the treatment of wastewater from heavy metals after the technological process. There are several mechanisms of binding of heavy metals by biosorption, including: microprecipitation, ion exchange, physisorption and chemisorption. The dominant mechanism is ion exchange with the use of brown marine macroalgae. The use of a natural ion exchanger from brown marine macro-algae allows the sequestration of positively charged metal ions such as copper, zinc, cobalt, cadmium, lead and others [Pozdniakova et al. 2016].

In many scientific centers, research is being conducted on the use of algae for wastewater treatment from biogenic compounds, heavy metals and medicines. There are many species of algae, but not all of them are suitable for use in wastewater treatment. Additionally, each should be approached individually for a given technological process. This issue is wide, which causes many factors affecting the final effect of the process [Kondzior 2017]. Algae are also used for water quality monitoring and toxicity tests [Czaplicka-Kotas 2007, Szczukocki et al. 2015].

The purpose of this paper is to determine the effect of heavy metals on the photosynthetic pigments of chlorophyll $\mathrm{a}, \mathrm{b}$ and the carotenoids found in the cells of Chlorella vulgaris algae. The content of pigments as well as their quantitative ratio, has a direct effect on the ability and the intensity of the photosynthesis process performed by the autotrophic species of algae. These organisms are distinguished by their resistance to the heavy metal content in the environment. The algae species that exhibit stress resistance due to increased heavy metals may be used for phytoremediation of the aquatic environments [Piotrowska-Niczyporuk and Bajguz, 2015].

\section{MATERIAL AND METHODS}

Chlorella vulgaris algae from the Department of Plant Biochemistry and Toxicology, University of Bialystok were used in the study. BG-11 was used to grow algae. The composition of BG-11 medium used for cultivation of Chlorella vulgaris is shown in Table 1.

The experiment was carried out in one batch using 5 dilutions of test compound. The reference sample was a test without a test compound. The tests were carried out in six interconnected bottles-gas-washing with the capacity of $200 \mathrm{~cm}^{3}$. Air was introduced to all gas-washing-bottles by means of a mini air compressor. The aeration system is equipped with a suitable filter to protect the algae from air pollution. In order to determine the effect of $\mathrm{CuSO}_{4} \cdot 5 \mathrm{H}_{2} \mathrm{O}$ on the Chlorella vulgaris algae, solutions of the test compound were prepared. The amounts of $15 ; 10 ; 7.5 ; 5$ and $2.5 \mathrm{~cm}^{3}$ $\mathrm{CuSO}_{4} \cdot 5 \mathrm{H}_{2} \mathrm{O}$ solution were added correspondingly at a concentration of $1.5 \mathrm{mg} / \mathrm{dm}^{3}$ to the gaswashing-bottles. The gas-washing-bottles were then filled with BG-11 to $150 \mathrm{~cm}^{3}$ and sterilized. In the samples tested, $\mathrm{CuSO}_{4} \cdot 5 \mathrm{H}_{2} \mathrm{O}$ concentration was $0.15 ; 0.1 ; 0.075 ; 0.05$ and $0.025 \mathrm{mg} / \mathrm{dm}^{3}$. Concentrated algae in the amount of $2 \mathrm{~cm}^{3}$ were added to each gas-washing-bottle. In order to determine the effect of $\mathrm{ZnSO}_{4} \cdot 7 \mathrm{H}_{2} \mathrm{O}$ on Chlorella vulgaris algae, the appropriate amounts were weighed: $15 ; 7.5 ; 3.75 ; 1.875 ; 0.938 \mathrm{mg}$ com- 
Table 1. Composition of BG-11 medium used for cultivation of Chlorella vulgaris

\begin{tabular}{|c|c|}
\hline Component & Value $\left(\mathrm{mg} / \mathrm{dm}^{3}\right)$ \\
\hline $\mathrm{NaNO}_{3}$ & 1500 \\
\hline $\mathrm{K}_{2} \mathrm{HPO}_{4}$ & 40 \\
\hline $\mathrm{MgSO}_{4} \cdot 7 \mathrm{H}_{2} \mathrm{O}$ & 75 \\
\hline $\mathrm{CaCl}_{2} \cdot 2 \mathrm{H}_{2} \mathrm{O}$ & 36 \\
\hline $\mathrm{C}_{6} \mathrm{H}_{8} \mathrm{O}_{7}$ & 6 \\
\hline$\left(\mathrm{NH}_{4}\right)_{5}\left[\mathrm{Fe}\left(\mathrm{C}_{6} \mathrm{H}_{4} \mathrm{O}_{7}\right)_{2}\right]$ & 6 \\
\hline $\mathrm{C}_{10} \mathrm{H}_{16} \mathrm{~N}_{2} \mathrm{O}_{8}$ & 1 \\
\hline $\mathrm{Na}_{2} \mathrm{CO}_{3}$ & 20 \\
\hline $\mathrm{H}_{3} \mathrm{BO}_{3}$ & \\
\hline $\mathrm{MnCl}_{2} \cdot 4 \mathrm{H}_{2} \mathrm{O}$ & 2.86 \\
\hline $\mathrm{ZnSO}_{4} \cdot 7 \mathrm{H}_{2} \mathrm{O}$ & 1.81 \\
\hline $\mathrm{NaMoO}_{4} \cdot 2 \mathrm{H}_{2} \mathrm{O}$ & 0.222 \\
\hline $\mathrm{CuSO}_{4} \cdot 5 \mathrm{H}_{2} \mathrm{O}$ & Microelements \\
\hline $\mathrm{Co}_{\left(\mathrm{NO}_{3}\right)_{2} \cdot 6 \mathrm{H}_{2} \mathrm{O}}$ & 0.39 \\
\hline
\end{tabular}

pound and added to the individual gas-washingbottles. The gas-washing-bottles were then filled with BG-11 to $150 \mathrm{~cm}^{3}$ and sterilized. In the samples tested, $\mathrm{ZnSO}_{4} \cdot 7 \mathrm{H}_{2} \mathrm{O}$ concentration was 100 ; $50 ; 25 ; 12,5$ and $6,25 \mathrm{mg} / \mathrm{dm}^{3}$. Concentrated algae in the amount of $3 \mathrm{~cm}^{3}$ of were added to each gas-washing-bottle. Cultures were conducted at $25^{\circ} \mathrm{C}$ using variable light with two fluorescents lamp (Zext F8T4/6400K 8W) (light phase - 10 hours, $140 \mu \mathrm{mol} \mathrm{m} \mathrm{m}^{-2} \mathrm{~s}^{-1}$ (PAR), dark phase -14 hours in the dark).

The pigment content was measured spectrophotometrically with a Hach Lange DR 5000 spectrophotometer. For this purpose, a $5 \mathrm{~cm}^{3}$ culture was taken as a test sample. The test sample was centrifuged at 4500 RPM for 10 minutes using the MPW-352R centrifuge. The supernatant was decanted and $5 \mathrm{~cm}^{3}$ of $90 \%$ methanol was added to the centrifuged mass of the algae. Then, the test-tubes were closed with a bacteriological stopper and subsequently mixed and placed in a steam bath set at $60^{\circ} \mathrm{C}$ for 10 minutes. After this time, the sample was centrifuged again for 10 minutes at 4500 RPM and the resulting supernatant was subjected to spectrophotometric analysis at 470; 652 and $665 \mathrm{~nm}$ wavelengths. The test specimens were taken daily before the light phase. The pigment content was calculated according to the formulas [Xiong et al., 2016]:

$$
\begin{aligned}
& \text { Chlorophyll } a=16.82 A_{665}-9.28 A_{652}\left(\frac{\mathrm{mg}}{\mathrm{dm}^{3}}\right) \\
& \text { Chlorophyll } b=36.92 A_{652}-16.54 A_{665}\left(\frac{\mathrm{mg}}{\mathrm{dm}^{3}}\right) \\
& C_{\text {carotenoid }}=\frac{\left(1000 A_{470}-1.91 C_{a}-95.15 C_{b}\right)}{225}\left(\frac{\mathrm{mg}}{\mathrm{dm}^{3}}\right)
\end{aligned}
$$

\section{RESULTS AND DISCUSSION}

Spectrophotometric analyzes of pigments in Chlorella vulgaris algae showed changes in their concentration relative to the control sample. Reduction of the pigment content was associated with an increase in the copper concentration in the culture medium and incubation time. On the basis of the research it was found that Chlorella vulgaris can grow in an environment of high copper content. The chlorophyll a content after 7 days of incubation decreased with respect to the control sample for $\mathrm{CuSO}_{4} \cdot 5 \mathrm{H}_{2} \mathrm{O}: 0.15 ; 0.1 ; 0.075$; 0.05 and $0.025 \mathrm{mg} / \mathrm{dm}^{3}$, by $63 \% ; 59 \% ; 50 \% ; 47 \%$ and $39 \%$, respectively. The content of chlorophyll $\mathrm{a}$ in individual days of incubation is shown in Table 2 and Figure 1. The content of chlorophyll $b$ after 7 days of incubation decreased with respect to the same concentration order (from the highest to lowest concentration) by $58 \% ; 56 \% ; 45 \%$; $43 \%$ and $26 \%$. The content of chlorophyll $\mathrm{b}$ in individual days of incubation is shown in Table 3 and Figure 2.

The carotenoid content after 7 days of incubation decreased with respect to the control for $\mathrm{CuSO}_{4} \cdot 5 \mathrm{H}_{2} \mathrm{O}: 0.15 ; 0.1 ; 0.075 ; 0.05$ and 0.025 $\mathrm{mg} / \mathrm{dm}^{3}$, by $60 \% ; 57 \%$; $49 \%$; $46 \%$ and $40 \%$, respectively. The content of carotenoid in individual days of incubation is shown in Table 4 and Figure 3.

The effect of copper on the content of photosynthetic dyes in Chlorella vulgaris algae cells and the pigment ratio after 7 days of exposure is 
Table 2. Effect of $\mathrm{CuSO}_{4} \cdot 5 \mathrm{H}_{2} \mathrm{O}$ on the chlorophyll a content in Chlorella vulgaris cells from the day of incubation

\begin{tabular}{|c|c|c|c|c|c|c|c|c|}
\hline \multirow{3}{*}{$\begin{array}{l}\text { Concentration } \\
\text { of } \mathrm{CuSO}_{4} \cdot 5 \mathrm{H}_{2} \mathrm{O} \\
\qquad\left(\mathrm{mg} / \mathrm{dm}^{3}\right)\end{array}$} & \multicolumn{8}{|c|}{ Day of incubation (day) } \\
\hline & 0 & 1 & 2 & 3 & 4 & 5 & 6 & 7 \\
\hline & \multicolumn{8}{|c|}{ Chlorophyll a content $\left(\mathrm{mg} / \mathrm{dm}^{3}\right)$} \\
\hline Control sample & \multirow{6}{*}{4.91} & 3.98 & 7.28 & 10.54 & 9.55 & 18.80 & 23.98 & 32.87 \\
\hline 0.025 & & 4.27 & 6.51 & 8.24 & 7.27 & 14.35 & 18.74 & 20.02 \\
\hline 0.05 & & 4.27 & 5.90 & 8.30 & 6.58 & 12.81 & 15.16 & 17.20 \\
\hline 0.075 & & 4.27 & 6.57 & 6.51 & 6.99 & 11.25 & 13.77 & 16.39 \\
\hline 0.10 & & 4.07 & 5.99 & 7.02 & 6.00 & 10.43 & 12.47 & 13.39 \\
\hline 0.15 & & 4.56 & 6.06 & 6.92 & 5.99 & 9.93 & 11.55 & 12.20 \\
\hline
\end{tabular}

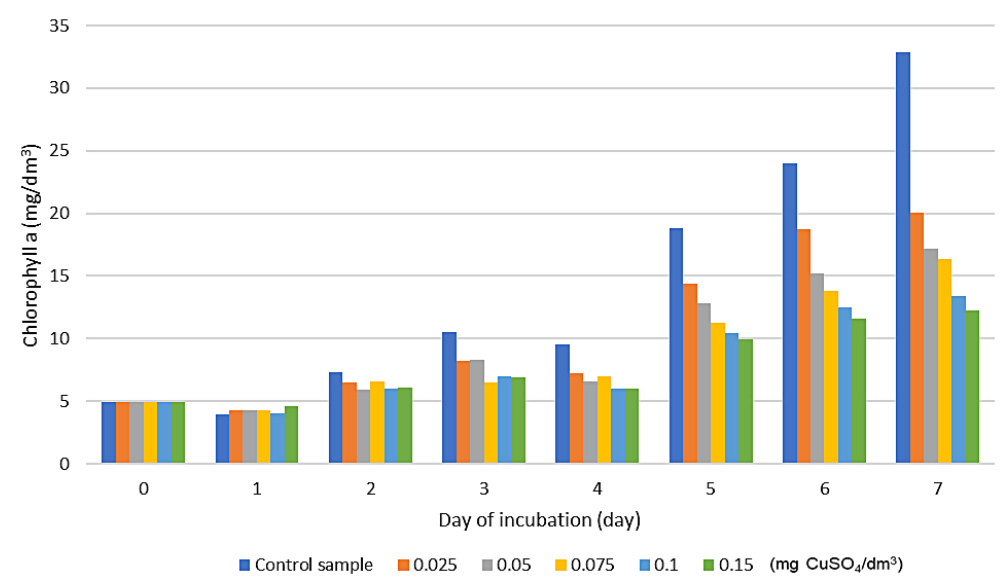

Figure 1. Graph of the influence of copper (II) sulphate on the chlorophyll a content in Chlorella vulgaris cells from the day of incubation

Table 3. Effect of $\mathrm{CuSO}_{4} \cdot 5 \mathrm{H}_{2} \mathrm{O}$ on the chlorophyll b content in Chlorella vulgaris cells from the day of incubation

\begin{tabular}{|c|c|c|c|c|c|c|c|c|}
\hline \multirow{3}{*}{$\begin{array}{l}\text { Concentration } \\
\text { of } \mathrm{CuSO}_{4} \cdot 5 \mathrm{H}_{2} \mathrm{O} \\
\qquad\left(\mathrm{mg} / \mathrm{dm}^{3}\right)\end{array}$} & \multicolumn{8}{|c|}{ Day of incubation (day) } \\
\hline & 0 & 1 & 2 & 3 & 4 & 5 & 6 & 7 \\
\hline & \multicolumn{8}{|c|}{ Chlorophyll b content $\left(\mathrm{mg} / \mathrm{dm}^{3}\right)$} \\
\hline Control sample & \multirow{6}{*}{3.29} & 2.01 & 3.18 & 4.87 & 5.36 & 8.84 & 12.05 & 14.32 \\
\hline 0.025 & & 2.19 & 2.96 & 3.68 & 3.97 & 6.73 & 9.17 & 10.66 \\
\hline 0.05 & & 2.00 & 2.79 & 3.96 & 4.01 & 6.16 & 7.07 & 8.16 \\
\hline 0.075 & & 2.00 & 2.94 & 3.02 & 3.71 & 5.11 & 6.11 & 7.90 \\
\hline 0.10 & & 2.00 & 2.75 & 3.35 & 3.44 & 5.19 & 5.75 & 6.31 \\
\hline 0.15 & & 2.10 & 2.91 & 3.45 & 3.29 & 4.89 & 5.62 & 5.95 \\
\hline
\end{tabular}

shown in Figure 4. In Figure 4, in the case of the concentration of $0.025 \mathrm{mg} / \mathrm{dm}^{3}$, there is a slight increase in the content of chlorophyll $b$; hence, the ratio of chlorophyll a to $b$ decreases, whereas the ratio of overall chlorophyll to carotenoids increases, which indicates a reduction in the content of carotenoids. This may show some changes in the metabolism of the body. To a lesser extent, this situation repeated itself at a concentration of $0.075 \mathrm{mg} / \mathrm{dm}^{3}$. This trend, however, does not change in the same way as the copper content in the substrate increases. In other concentrations, the pigment ratios are similar to those in the control sample with a slight downward trend.

The BG-11 medium contains copper as a micronutrient at a concentration of $0.079 \mathrm{mg} / \mathrm{dm}^{3}$ in the form of a $\mathrm{CuSO}_{4} \cdot 5 \mathrm{H}_{2} \mathrm{O}$ compound. Copper is essential for normal metabolic processes in algae. The composition of the medium should be considered a background, but its content in BG-11 medium is so large that it should be taken into account. In the study on the influence of copper on algae 


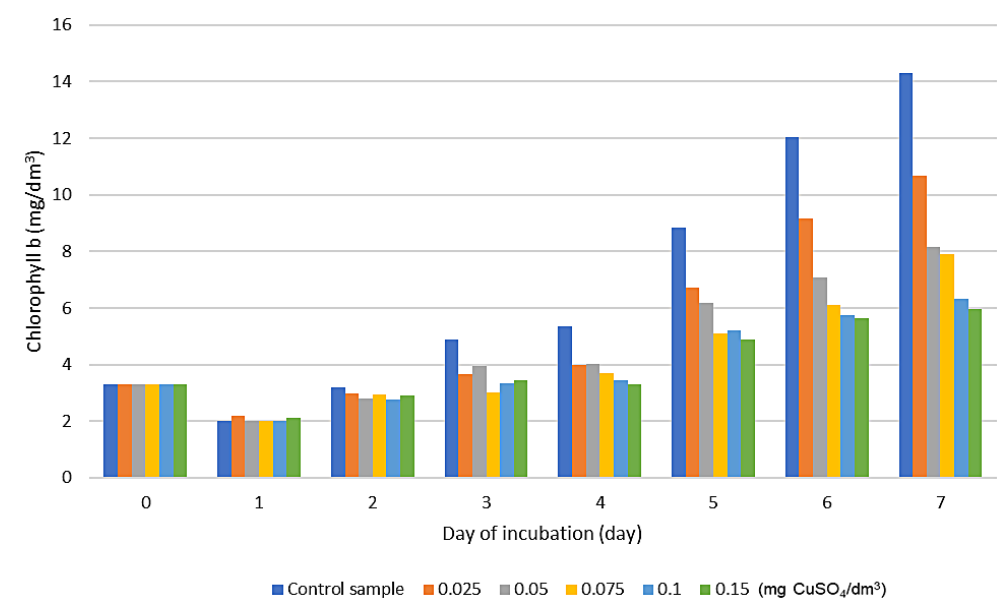

Figure 2. Graph of the influence of copper(II) sulphate on the chlorophyll b content in Chlorella vulgaris cells from the day of incubation

Table 4. Effect of $\mathrm{CuSO}_{4} \cdot 5 \mathrm{H}_{2} \mathrm{O}$ on the carotenoid content in Chlorella vulgaris cells from the day of incubation

\begin{tabular}{|c|c|c|c|c|c|c|c|c|}
\hline \multirow{3}{*}{$\begin{array}{l}\text { Concentration } \\
\text { of } \mathrm{CuSO}_{4} \cdot 5 \mathrm{H}_{2} \mathrm{O} \\
\left(\mathrm{mg} / \mathrm{dm}^{3}\right)\end{array}$} & \multicolumn{8}{|c|}{ Day of incubation (day) } \\
\hline & 0 & 1 & 2 & 3 & 4 & 5 & 6 & 7 \\
\hline & \multicolumn{8}{|c|}{ Carotenoid content $\left(\mathrm{mg} / \mathrm{dm}^{3}\right)$} \\
\hline Control sample & \multirow{6}{*}{0.98} & 1.10 & 2.03 & 2.79 & 2.71 & 5.31 & 6.47 & 8.71 \\
\hline 0.025 & & 1.16 & 1.84 & 2.25 & 1.95 & 4.06 & 5.04 & 5.26 \\
\hline 0.05 & & 1.22 & 1.64 & 2.25 & 1.85 & 3.57 & 4.37 & 4.74 \\
\hline 0.075 & & 1.19 & 1.79 & 1.76 & 1.90 & 3.22 & 3.91 & 4.40 \\
\hline 0.10 & & 1.14 & 1.62 & 1.89 & 1.70 & 2.85 & 3.53 & 3.75 \\
\hline 0.15 & & 1.33 & 1.66 & 1.87 & 1.60 & 2.73 & 3.37 & 3.50 \\
\hline
\end{tabular}

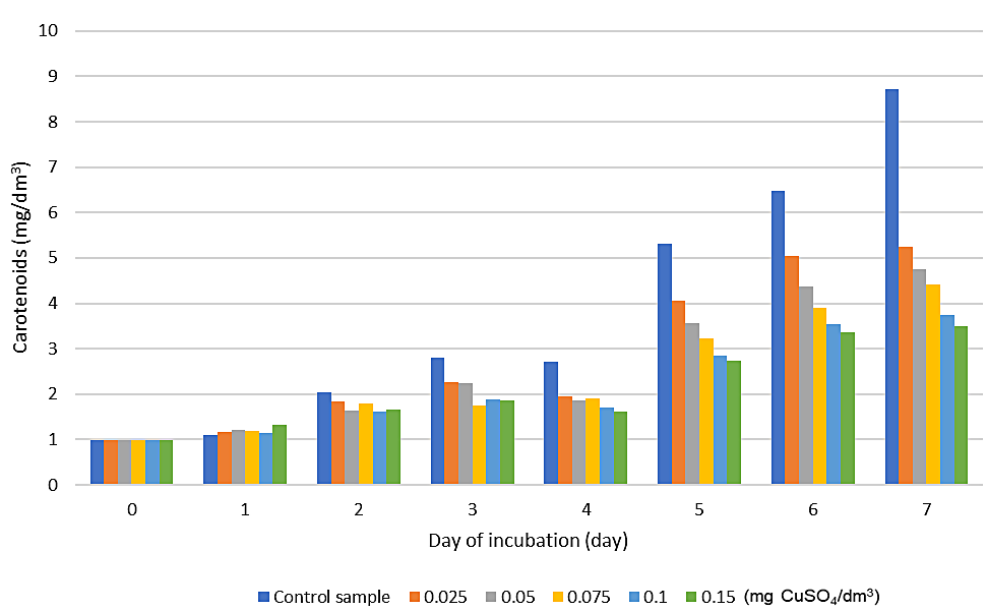

Figure 3. Graph of the influence of copper(II) sulphate on the carotenoid content in Chlorella vulgaris cells from the day of incubation

from Chlorella vulgaris, addition of $0.025 \mathrm{mg} /$ $\mathrm{dm}^{3}$ results in a reduction of chlorophyll a content by $39 \%$, chlorophyll b by $26 \%$ and carotenoids by $40 \%$ after 7 days of incubation. According to the compound for the compound $\mathrm{CuSO}_{4} \cdot 5 \mathrm{H}_{2} \mathrm{O}$, the $\mathrm{EC}_{50}$ value was determined to be $0.1 \mathrm{mg} /$ $\mathrm{dm}^{3} / 4 \mathrm{~h}$ for Scenedesmus quadricauda. Chlorella vulgaris and Scenedesmus quadricauda belong to the same genus Chlorophyta. In the conducted research it was shown that Chlorella vulgaris algae may develop during the 7-day exposure to the increased copper content. The growth of algae Chlorella vulgaris is clearly inhibited as the copper content in the culture medium increases. The 


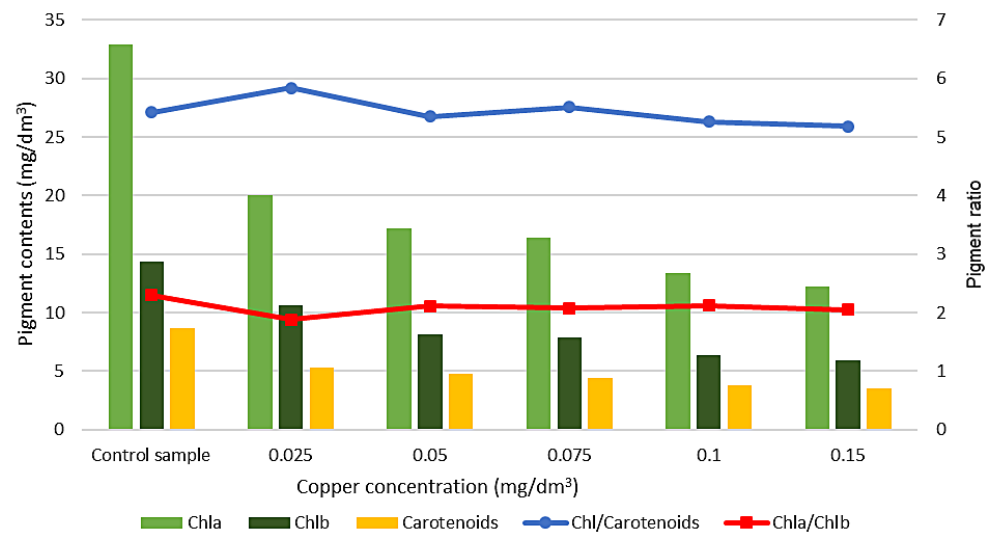

Figure 4. The effect of copper on the content of photosynthetic dyes in Chlorella vulgaris algae cells and the pigment ratio after 7 days of exposure, Chla - chlorophyll a, Chlb - chlorophyll b, Chl - overall chlorophyll (sum of chlorophyll a and b)

studies did not reach the concentration at which the death of algae cultures would occur. Mallick [2004] describes the influence of copper on the behavior of enzymatic and nonenzymatic mechanisms in Chlorella vulgaris algae cells. The researcher showed that the addition of copper to the culture medium increases the concentration of carotenoids, lipid peroxidation and activity of superoxide dismutase (SOD) with a simultaneous reduction of catalase activity, cellular GSH, ascorbate peroxidase, glutathione reductase, ascorbate and $\mathrm{K}^{+}$pool. The studies considered the following concentrations: $3 ; 2.5 ; 2 ; 1 ; 0.5 ; 0.25 \mathrm{mg} \mathrm{Cu} /$ $\mathrm{dm}^{3}$ and control. The general condition of algae cultures was examined by analyzing the content of chlorophyll a and the results obtained from the highest concentration to the lowest as well as the control sample: $7.5 ; 9.6 ; 12.2 ; 16.6 ; 20.6 ; 24.6$ and $23.4 \mathrm{mg} / \mathrm{dm}^{3}$, respectively. A live culture of algae Chlorella vulgaris was observed even in the tests at a concentration of $3 \mathrm{mg} \mathrm{Cu} / \mathrm{dm}^{3}$, with an increase of $32 \%$ compared to the control.

The second study analyzed the effect of zinc(II) sulphate on the growth of Chlorella vulgaris. The study used 5 concentrations of $\mathrm{ZnSO}_{4} \cdot 7 \mathrm{H}_{2} \mathrm{O}: 100 ; 50 ; 25 ; 12.50$ and $6.25 \mathrm{mg}$ $\mathrm{ZnSO}_{4} / \mathrm{dm}^{\frac{2}{3}}$ and a control sample. It has been shown to slow down the development of algal cultures along with increasing the concentration of zinc(II) sulphate in the culture medium. It was found that at a concentration of $100 \mathrm{mg} \mathrm{ZnSO} /$ $\mathrm{dm}^{3}$, the culture of Chlorella vulgaris died after 5 days of incubation. The concentration of chlorophyll a, compared to the control, decreased after 7 days of incubation from the largest concentration of zinc to the smallest by $100 \% ; 80 \% ; 65 \% ; 55 \%$ and $35 \%$ respectively. The effect of $\mathrm{ZnSO}_{4} \cdot 7 \mathrm{H}_{2} \mathrm{O}$ on the chlorophyll a content in Chlorella vulgaris cells from the day of incubation is shown in Table 5 and Figure 5 . The chlorophyll b content after 7 days of incubation decreased with respect to the control for $\mathrm{ZnSO}_{4} \cdot 7 \mathrm{H}_{2} \mathrm{O}: 100 ; 50 ; 25 ; 12.5$ and $6.25 \mathrm{mg} / \mathrm{dm}^{3}$, by $100 \% ; 79 \% ; 59 \% ; 55 \%$ and $31 \%$, respectively. The content of chlorophyll $b$ in individual days of incubation is shown in Table 6 and Figure 6.

The carotenoid content after 7 days of incubation decreased with respect to the control for

Table 5. Effect of $\mathrm{ZnSO}_{4} \cdot 7 \mathrm{H}_{2} \mathrm{O}$ on the chlorophyll a content in Chlorella vulgaris cells from the day of incubation

\begin{tabular}{|c|c|c|c|c|c|c|c|c|}
\hline \multirow{3}{*}{$\begin{array}{l}\text { Concentration } \\
\text { of } \mathrm{ZnSO}_{4} \cdot 7 \mathrm{H}_{2} \mathrm{O} \\
\qquad\left(\mathrm{mg} / \mathrm{dm}^{3}\right)\end{array}$} & \multicolumn{8}{|c|}{ Day of incubation (day) } \\
\hline & 0 & 1 & 2 & 3 & 4 & 5 & 6 & 7 \\
\hline & \multicolumn{8}{|c|}{ Chlorophyll a content $\left(\mathrm{mg} / \mathrm{dm}^{3}\right)$} \\
\hline Control sample & \multirow{6}{*}{2.42} & 3.93 & 7.62 & 12.05 & 15.51 & 24.49 & 35.51 & 43.33 \\
\hline 6.25 & & 3.55 & 6.83 & 10.37 & 11.29 & 18.86 & 23.96 & 28.07 \\
\hline 12.5 & & 3.58 & 5.94 & 8.94 & 11.16 & 14.00 & 18.60 & 19.38 \\
\hline 25 & & 3.53 & 5.52 & 7.71 & 9.66 & 12.03 & 12.33 & 15.02 \\
\hline 50 & & 2.59 & 3.76 & 4.79 & 5.40 & 5.68 & 7.20 & 8.47 \\
\hline 100 & & 2.65 & 2.71 & 2.37 & 1.07 & 0.31 & 0.08 & 0.03 \\
\hline
\end{tabular}




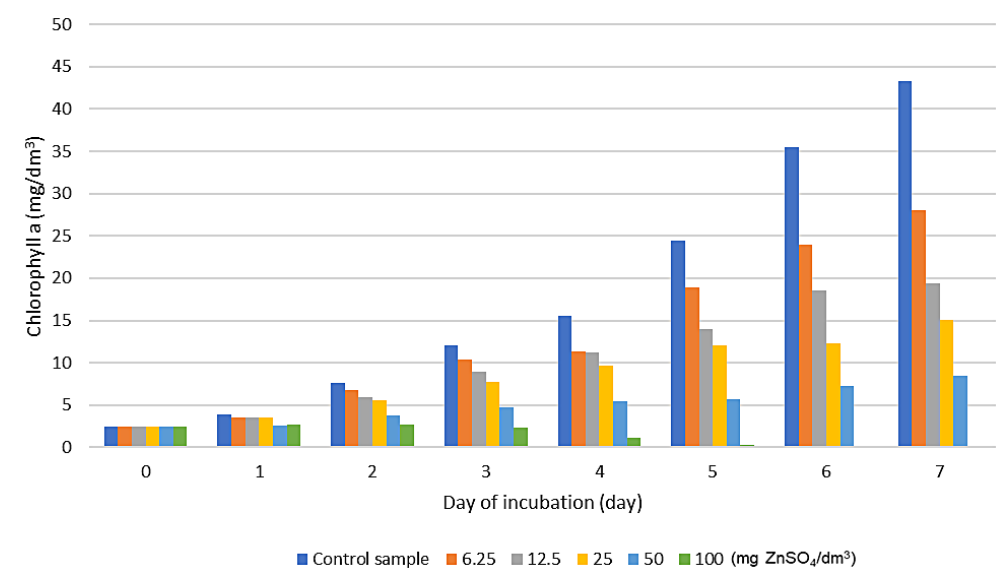

Figure 5. Graph of the influence of zinc(II) sulphate on the chlorophyll a content in Chlorella vulgaris cells from the day of incubation

Table 6. Effect of $\mathrm{ZnSO}_{4} \cdot 7 \mathrm{H}_{2} \mathrm{O}$ on the chlorophyll $\mathrm{b}$ content in Chlorella vulgaris cells from the day of incubation

\begin{tabular}{|c|c|c|c|c|c|c|c|c|}
\hline \multirow{3}{*}{$\begin{array}{l}\text { Concentration } \\
\text { of } \mathrm{ZnSO} \cdot 7 \mathrm{H}_{2} \mathrm{O} \\
\left(\mathrm{mg} / \mathrm{dm}^{3}\right)\end{array}$} & \multicolumn{8}{|c|}{ Day of incubation (day) } \\
\hline & 0 & 1 & 2 & 3 & 4 & 5 & 6 & 7 \\
\hline & \multicolumn{8}{|c|}{ Chlorophyll b content $\left(\mathrm{mg} / \mathrm{dm}^{3}\right)$} \\
\hline Control sample & \multirow{6}{*}{0.96} & 1.50 & 3.12 & 4.66 & 6.40 & 10.39 & 13.89 & 17.29 \\
\hline 6.25 & & 1.60 & 2.90 & 4.28 & 5.02 & 8.69 & 9.46 & 11.87 \\
\hline 12.5 & & 1.62 & 2.78 & 3.52 & 4.81 & 6.58 & 7.61 & 7.74 \\
\hline 25 & & 1.48 & 2.41 & 3.17 & 4.09 & 5.37 & 5.05 & 7.13 \\
\hline 50 & & 1.29 & 2.11 & 2.21 & 2.62 & 2.95 & 2.98 & 3.68 \\
\hline 100 & & 0.98 & 1.17 & 1.08 & 0.98 & 0.53 & 0.17 & 0.08 \\
\hline
\end{tabular}

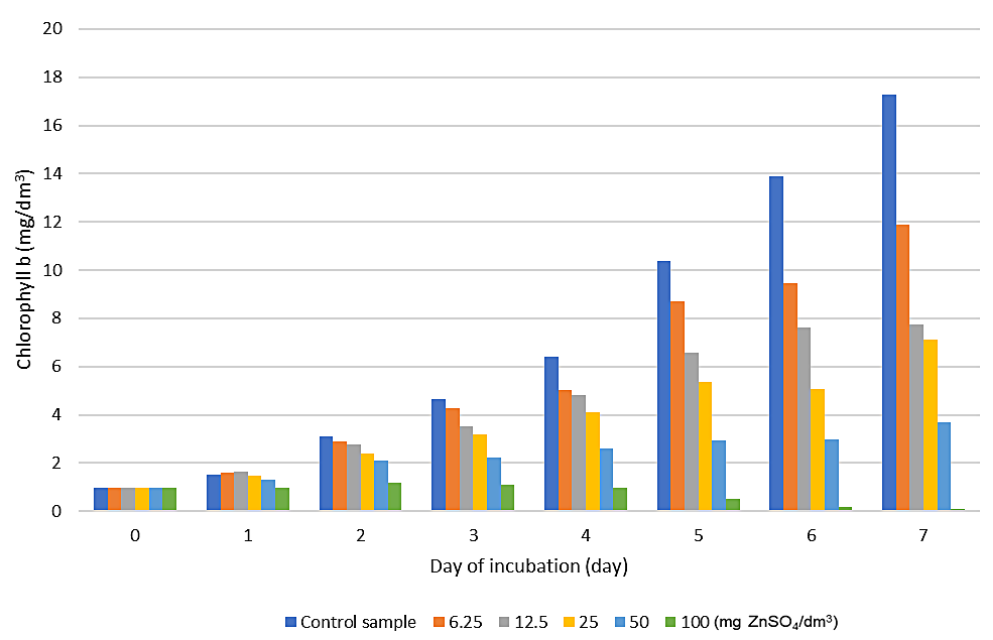

Figure 6. Graph of the influence of zinc(II) sulphate on the chlorophyll b content in Chlorella vulgaris cells from the day of incubation

$\mathrm{ZnSO}_{4} \cdot 7 \mathrm{H}_{2} \mathrm{O}: 100 ; 50 ; 25 ; 12.5$ and $6.25 \mathrm{mg} /$ $\mathrm{dm}^{3}$, by $100 \% ; 79 \% ; 66 \% ; 56 \%$ and $36 \%$, respectively. The content of carotenoid in individual days of incubation is shown in Table 7 and Figure 7. The effect of zinc on the content of photosynthetic dyes in Chlorella vulgaris algae cells and the pigment ratio after 7 days of exposure is shown in Figure 8.

In Figure 8, the ratio of pigments shows similar trends as in the case of the copper impact study. After 7 days of exposure to zinc, the ratio of chlorophyll a to $b$ in the $6.25 \mathrm{mg} / \mathrm{dm}^{3}$ sample decreas- 
Table 7. Effect of $\mathrm{ZnSO}_{4} \cdot 7 \mathrm{H}_{2} \mathrm{O}$ on the carotenoid content in Chlorella vulgaris cells from the day of incubation

\begin{tabular}{|c|c|c|c|c|c|c|c|c|}
\hline \multirow{3}{*}{$\begin{array}{l}\text { Concentration } \\
\text { of } \mathrm{ZnSO}_{4} \cdot 7 \mathrm{H}_{2} \mathrm{O} \\
\qquad\left(\mathrm{mg} / \mathrm{dm}^{3}\right)\end{array}$} & \multicolumn{8}{|c|}{ Day of incubation (day) } \\
\hline & 0 & 1 & 2 & 3 & 4 & 5 & 6 & 7 \\
\hline & \multicolumn{8}{|c|}{ Carotenoid content $\left(\mathrm{mg} / \mathrm{dm}^{3}\right)$} \\
\hline Control sample & \multirow{6}{*}{0.68} & 1.12 & 2.00 & 3.49 & 4.56 & 6.75 & 9.91 & 11.92 \\
\hline 6.25 & & 0.99 & 1.82 & 2.91 & 3.40 & 4.96 & 6.53 & 7.68 \\
\hline 12.5 & & 0.98 & 1.51 & 2.54 & 3.10 & 3.70 & 5.07 & 5.22 \\
\hline 25 & & 0.98 & 1.43 & 2.19 & 2.79 & 3.30 & 3.58 & 4.05 \\
\hline 50 & & 0.76 & 0.99 & 1.47 & 1.63 & 1.58 & 2.20 & 2.55 \\
\hline 100 & & 0.77 & 0.74 & 0.58 & 0.12 & 0.00 & 0.00 & 0.00 \\
\hline
\end{tabular}

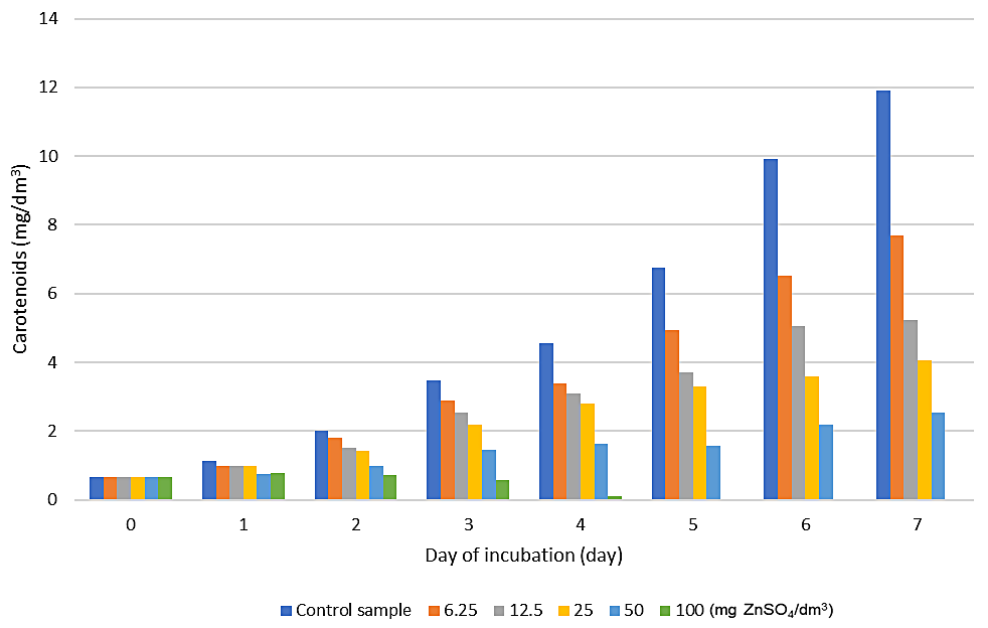

Figure 7. Graph of the influence of zinc(II) sulphate on the carotenoid content in Chlorella vulgaris cells from the day of incubation

es to 2.36 , from 2.51 in the control sample. The ratio of overall chlorophyll to carotenoids in the same sample slightly increases to 5.2, from 5.09 in the control sample. In the test with the zinc concentration of $25 \mathrm{mg} / \mathrm{dm}^{3}$, higher inclinations were noted, for the chlorophyll a to $\mathrm{b}$ ratio decreased to 2.11, in the case of general chlorophyll for carotenoids, an increase to 5.47 was observed. In this case, the content of chlorophyll b should be considered. In the test with the zinc concentration of $25 \mathrm{mg} / \mathrm{dm}^{3}$, the content of chlorophyll b on the 5th, 6th and 7th day of incubation reaches the concentrations of $5.37 ; 5.05$ and $7.13 \mathrm{mg} / \mathrm{dm}^{3}$, respectively. On the 7th day of exposure, a significant increase in the chlorophyll b content is noted. In the control sample, the trend line is not broken; the growth of algae is exponential. A characteristic point of stagnation, followed by an increase in the concentration of dyes, was observed. At lower zinc concentrations up to $12.5 \mathrm{mg} / \mathrm{dm}^{3}$, it occurs from 4 to 5 days or from 5 to 6 days, and at higher concentrations even from 6 to 7 days of incubation for the investigated dyes. In the trial with the zinc concentration of $100 \mathrm{mg} / \mathrm{dm}^{3}$ on the 5 th day of exposure, deaths of algae were observed. In the copper impact studies, such dependencies cannot be noticed, because in the control sample, as well as the tested samples of algae exposure to copper on the 4th day of incubation, these results differ from the predicted ones which may indicate an error during the analysis of dyes. Hou et al. [2018] presented a new issue related to nanoparticles the impact of which is not known and their use in industry is increasing. Researchers report that inhibition of Chlorella sp. algae influenced by zinc nanoparticles has been observed.

Wan Maznah et al. [2012] showed that Chlorella sp. and Chlamydomonas sp. can be good species for use in the biosorption of copper and zinc. It has been found that immobilization of algae using sodium alginate facilitated the separation and reuse of the beads from algae. Immobilization improved biosorption, compared to free algal cultures. However, they report a significant decrease in the number of cells in the first 6 hours of the experiment due to a high copper concentration of $5 \mathrm{mg} / \mathrm{dm}^{3}$, which was considered toxic to Chlorella vulgaris. The researchers did not notice a decrease in the algae culture with a zinc concentration of $5 \mathrm{mg} / \mathrm{dm}^{3}$. During growth, algae 


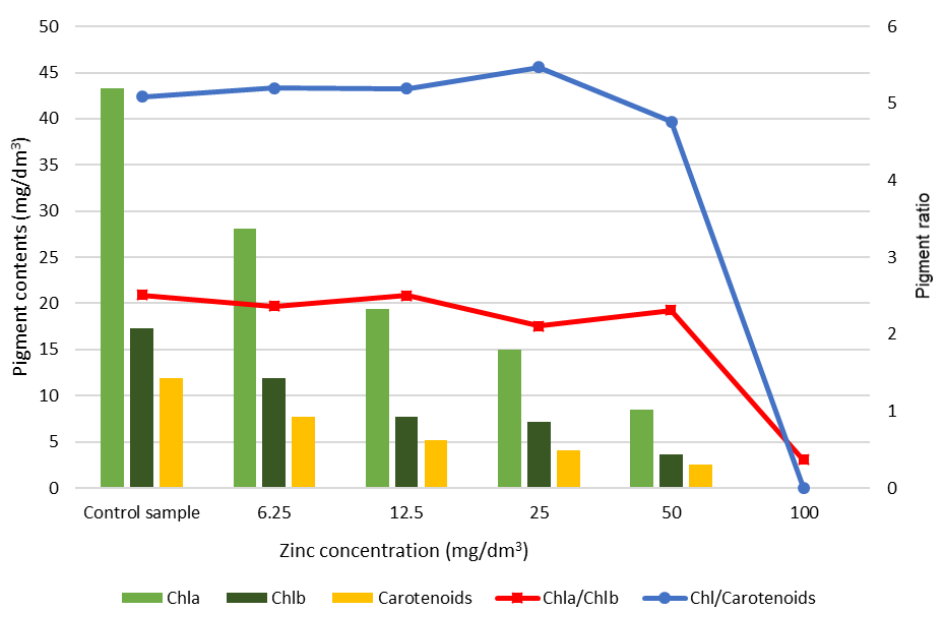

Figure 8. The effect of zinc on the content of photosynthetic dyes in Chlorella vulgaris algae cells and the pigment ratio after 7 days of exposure (at a concentration of $100 \mathrm{mg} \mathrm{ZnSO} / \mathrm{dm}^{3}$ the ratio of pigments $\mathrm{Chl} / \mathrm{Ca}$ rotenoids was assumed to be 0 ), Chla - chlorophyll a, Chlb - chlorophyll b, Chl - overall chlorophyll (sum of chlorophyll a and b)

secrete metabolites into the environment, which can reduce the amount of toxic heavy metal ions as a result of their chelation [Bajguz 2007]. The decline in the number of algae results in a lower resistance of algae cultures to the presence of heavy metals. Bajguz [2010] also reports that the growth of Chlorella vulgaris has been inhibited by heavy metals. In the study, heavy metal samples $(\mathrm{Cu}, \mathrm{Pb}$ and $\mathrm{Cd})$ were considered as a control and compared to the ones to which brassinolide and heavy metals were added. It was found that the application brassinolide contributed to the activation of enzymatic and nonenzymatic systems in Chlorella vulgaris. They demonstrated that the application of brassinolide is increasing the level of antioxidant enzymes (superoxide dismutase, the catalase and the peroxidase), the level of the ascorbate and the reduced glutathione. The obtained results showed that heavy metals after brassinolide addition have a more gentle effect on Chlorella vulgaris. Furthermore, Bajguz [2011] confirms that heavy metals reduce the intensity of important metabolic processes related to the transport of essential cells and ions from cellular sites, the process of photosynthesis and affect the reduction of important substances in cells such as enzymes, photosynthetic dyes and changes in protein content, sugars or fats in the algae cells. The researcher reports that the effect of heavy metals on algae can be reduced by using brassinosteroids, which prevent the loss of chlorophyll, sugars and proteins. Piotrowska-Niczyporuk et al. [2012] performed the test of exogenously applied phytohormones: auxins, jasmonic acid, cytokinins, polyamine, gbberellin on the growth and metabilism of Chlorella vulgaris algae treated with heavy metals. It was found that phytohormones such as auxins, gibberellins, cytokinins and polyamine reduced the effect of heavy metals on Chlorella vulgaris algae. They assume that this is related to blocking the entry of heavy metal into the cell and increasing the defensive response of the cell.

The algae species that are capable of growing in an environment with increased levels of heavy metals and carrying out biosorption are currently being sought. Piotrowska-Niczyporuk and Bajguz [2015] describe that hydroxyproline-rich glycoproteins capable of binding metals were found in the cell wall of Chlamydomonas reinhardtii. This species absorbed $\mathrm{Hg}, \mathrm{Cd}$ and $\mathrm{Pb}$ on the surface of the cell wall. If the metal is passed through the cell wall, there are intracellular defense mechanisms that bind metal through peptide and protein ligands. Algae cells have many ways of defending against the growing pollution of the environment in which they grow. Many of them have not been fully investigated yet. Zeraatka et al. [2016] describes that algae are a good candidate for the biosorption of heavy metals. They are characterized by the low cost of cultivation, high level of metal ions collection, selectivity in their collection and the possibility of large-scale cultivation. Before the implementation, a research on biochemical characteristics of substrates of microalgas and resulting benefits from applying them to the natural environment is required. The researcher reminds that an individual approach for a given technological process as well as estimation of costs are required in order to make it economically justifi- 
able. It is possible to combine wastewater treatment with algae and then use the produced biomass in other technological processes for energy production [Paniagua-Michel 2015]. Bulgariu and Gavrilescu [2015] describe that when designing bioremediation processes, one should take into account: process efficiency, which depends on the characteristics of microalgae (particle size, conditions of development, growth, etc.), the retention process (biosorbent dose, contact time, $\mathrm{pH}$ solution, temperature, heavy metals concentration, flow rate of aqueous solution). The efficiency of the process should first be designed on a smaller scale and then adapted to the industrial scale.

\section{CONCLUSIONS}

1. The influence of heavy metals $(\mathrm{Cu}$ and $\mathrm{Zn})$ on the reduction of photosynthetic dyes in Chlorella vulgaris algae cells was demonstrated.

2. The content of photosynthetic dyes decreased with the concentration of heavy metals.

3. The studies did not show a threshold for lethal concentration of copper(II) sulphate for algae from Chlorella vulgaris species.

4. After 7 days of incubation at the highest tested copper concentration of $0.15 \mathrm{mg} / \mathrm{dm}^{3}$, the algae cells of the Chlorella vulgaris species contain less chlorophyll a by $63 \%$, chlorophyll b by $58 \%$ and carotenoids by $60 \%$.

5 . The content of zinc in the culture medium at a concentration of $100 \mathrm{mg} / \mathrm{dm}^{3}$ caused the death of algae breeding of the Chlorella vulgaris species after 5 days of incubation.

6. After 7 days of incubation at a zinc concentration of $50 \mathrm{mg} / \mathrm{dm}^{3}$, the Chlorella vulgaris algae cells contain less chlorophyll a by $80 \%$, chlorophyll b by $79 \%$ and carotenoids by $79 \%$ in comparison to the control.

7. The algae of the Chlorella vulgaris species show the ability to grow in a culture medium with an increased content of heavy metals. It is required to extend the research with the ability to absorb heavy metals by algal cells.

\section{Acknowledgements}

The research was carried out at the Department of Chemistry, Biology and Biotechnology of the Bialystok University of Technology as part of the implementation of the statutory work No. S/WBiIŚ/3/2015.

\section{REFERENCES}

1. Bajguz A. 2007. Effect of brassinosteroids on algae cultures Chlorella vulgaris treated with selected phytohormones and stress factors. Publisher of the University of Bialystok (In Polish).

2. Bajguz A. 2010. An enhancing effect of exogenous brassinolide on the growth and antioxidant activity in Chlorella vulgaris cultures under heavy metals stress. Environmental and Experimental Botany, Vol. 68, 175-179.

3. Bajguz A. 2011. Suppression of Chlorella vulgaris Growth by Cadmium, Lead, and Copper Stress and Its Restoration by Endogenous Brassinolide. Arch Environ Contam Toxicol, Vol. 60, 406-416.

4. Bandurska H. 2007. Mineral nutrition of plants (In Polish) [IN:] Plant physiology. Kozłowska M. [ed.], Państwowe Wydawnictwo Rolnicze i Leśne, Poznań.

5. Bulgariu L., Gavrilescu M. 2015. Bioremediation of Heavy Metals by Microalgae [IN:] Handbook of marine microalgae biotechnology advances. Kim S-K. [ed.], 457-469.

6. Czaplicka-Kotas A. (2007). Studies on the impact of water quality on the production of photosynthetic pigments in Chlorella vulgaris algae for the needs of surface water biomonitoring (In Polish). Ochrona środowiska. 29(1).

7. Gabryś H., Kacperska A., Kopcewicz J., Lewak S., Starck Z., Strzałka K., Tretyn A. 2005. Plant physiology (In Polish) Kopcewicz i Lewaka [ed.], PWN Publishing House, Warsaw.

8. Hochmuth D. J., Asselman J., Schamphelare K.A.C. 2014. Are interactive effects of harmful algal blooms and copper pollution a concern for water quality management? Water Research, Vol. $60,41-53$.

9. Hou J., Wu Y., Li X., Wei B., Li S., Wang X. 2018. Toxic effects of different types of zinc oxide nanoparticles on algae, plants, invertebrates, vertebrates and microorganisms. Chemosphere, Vol. 193, 852-860.

10. Kondzior P. 2017. The use of algae and cyanobacteria in engineering and environmental protection (In Polish), [IN:] Monographs Inżynieria Środowiska - Młodym Okiem, Vol. 32, 65-81, Publishing house of the Bialystok University of Technology, Bialystok.

11. Mallick N. 2004. Copper-induced oxidative stress in the chlorophycean microalga Chlorella vulgaris: response of the antioxidant system. Journal of Plant Physiology, Vol. 161, 591-597.

12. Paniagua-Michel J. 2015. Bioremediation with Microalgae: Toward Sustainable Production of Biofuels [IN:] Handbook of marine microalgae biotechnology advances. Kim S-K. [ed.], 471-482. 
13. Piotrowska-Niczyporuk A., Bajguz A., Zambrzycka E., Godlewska-Żyłkiewicz B. 2012. Phytohormones as regulators of heavy metal biosorption and toxicity in green alga Chlorella vulgaris (Chlorophyceae). Plant Physiology and Biochemistry, Vol. 52, 52-65.

14. Piotrowska-Niczyporuk, A., Bajguz, A. 2015. The share of algae in the phytoremadation of water environments contaminated with heavy metals. Biodiversity - from the cell to the ecosystem. Functioning of plants and fungi Environmentexperiment-learning (In Polish). Bajguz A. and Ciereszko I. [ed.], 239-252.

15. Pozdniakova T.A., Mazur L.P., Boaventura R.A.R., Vilar V.J.P. 2016. Brown macro-algae as natural cation exchangers for the treatment of zinc containing wastewaters generated in the galvanizing process. Journal of Cleaner Production, Vol. 119, 38-49.

16. Szczukocki D., Krawczyk B., Czarny K. Romanowska-Duda Z. (2015). Toxicity tests using green algae of the genus Chlorella sp. and Scenedesmus armatus. Technology of growing microalgae in closed bioreactors with $\mathrm{CO} 2$ recycling and other biogas wastes (In Polish), Szwaja
S. [ed.], Wydawnictwo Instytut Maszyn Cieplnych Politechniki Częstochowskiej, Częstochowa, 287-298.

17. Wan Maznah W.O., Al-Fawwaz A.T., Surif M. 2012. Biosorption of copper and zinc by immobilised and free algal biomass, and the effects of metal biosorption on the growth and cellular structure of Chlorella sp. and Chlamydomonas sp. isolated from rivers in Penang, Malaysia. Journal of Environmental Sciences, 24(8), 1386-1393.

18. Weglarzy K. 2007. Heavy metals - the source of pollution and the effect on the environment (In Polish). Wiadomości Zootechniczne, XLV(3), 31-38.

19. Xiong, J.-Q., Kurade, M.B., Abou-Shanab, R.A.I., Ji, M.-K., Choi, J., Oh Kim, J., Jeon, B.-H. 2016. Biodegradation of carbamazepine using freshwater microalgae Chlamydomonas mexicana and Scenedesmus obliquus and the determination of its metabolic fate. Bioresource Technology, 205, 183-190.

20. Zeraatkar A. K., Ahmadzadeh H., Talebi A. F., Moheimani N. R., McHenry M. P. 2016. Potential use of algae for heavy metal bioremediation, a critical review. Journal of Environmental Management, Vol. 181, 817-831. 